\title{
Effect of Honey Bee Propolis on Certain Human Bacterial Species (Bacillus subtilis, Escherichia coli and Klebsiella pneumoniae)
}

\author{
El-Dessouki, S.A. ${ }^{1}$; El-Khawass, K.A.M.H. ${ }^{1}$; Abul-Enein, H.T. ${ }^{2}$ and H. A. Tantawy ${ }^{2}$ \\ 1- Department of Plant Protection, Faculty of Agriculture, Al- Azhar University, Cairo, Egypt. \\ 2- Plant Protection Research Institute, Agri. Res. Centre, Ministry of Agric., Dokki, Giza,Egypt.
}

\begin{abstract}
Using propolis ethanol $70 \%$ extract on the growth of three bacterial species showed that by increasing extract concentration, the zone of growth inhibition increased in the three tested bacterial species where, at 8 ppm the growth inhibition zones were 14.3, 21.3 and $30.0 \mathrm{~mm}$ for Bacillus subtilis, Escherichia coli and Klebsiella pneumoniae, respectively. On the other hand the lowest concentration (2ppm) showed the lowest growth inhibition for all bacterial species $(9.3,15.3$ and $22.6 \mathrm{~mm}$, respectively). The medium concentration (4ppm) was intermediate. However, propolis-water resulted no growth inhibition except for the B. subtilis which was affected by 4 and 8 ppm; (4.3 and $8.0 \mathrm{~mm}$ extract growth inhibition respectively).
\end{abstract}

\section{Introduction}

The honey bee (Apis mellifera L.) is considered as one of the most important beneficial insects. Honey bee colonies give nutritional, medical and industrial products (Honey, bee-wax, royal jelly, pollen grains, propolis and bee venom).

Propolis (bee glue) is a hard resinous and aromatic material derived by bees from plant juices and used to seal openings in the hives and to varnish and disinfect the cells after emergence of the workers and drones before the queen relays eggs in them. It contains pollen, resins, waxes and large amount of flavonoids which are found in photosynthesizing cells. Flavonoids have many biological effects in animal systems and have received some attention from pharmacologists (Havsteen 1983, Zumla and Lulat 1989 and Dandiya 1991).

B. subtilis is a Gram-positive, rod-shaped bacterium. It has the ability to form a tough, protective endospore, allowing the organism to tolerate extreme environmental conditions and is a normal gut commensal in humans.

E.coli is a Gram-negative, rodshaped bacterium that is commonly found in the lower intestine of warm-blooded organisms. Most $E$. coli strains are harmless, but some can cause food poisoning in humans. The harmless strains are part of the normal flora of the gut, and can benefit their hosts by producing vitamin $\mathrm{K}$ and by preventing the establishment of pathogenic bacteria within the intestine. The increasing resistance of $E$. coli, bacteria most frequently isolated during urinary tract infection to diverse antibiotics is an international public health problem making new solutions essential (Philippe et al. (2011)

K. pneumoniae is a Gram-negative, rod shaped bacterium. Although found in the normal flora of the mouth, skin, and intestines, it can cause destructive changes to human lungs if aspirated. In recent years, $K$. pneumoniae have become important pathogens in nosocomial infections.

\section{Material and methods}

In this experiment the used propolis samples were collected from the apiary at El-Quanater El-Khairia, El-Qualiobia Governorate during 2009, 2010 and 2011. The aim of study was to test different propolis extracts on the growth of some bacteria species ( $B$. subtilis, E. coli and K. pneumoniae). Two propolis extracts were used (propolis-ethanol extract and propolis-water extract) in three concentrations (2, 4 and $8 \mathrm{ppm})$ :

\section{Propolis Preparations:}

\section{Propolis-Ethanol Extracts (PEE):}

To get ethanol extract; $10 \mathrm{~g}$ of row propolis was dissolved in $100 \mathrm{ml}$ ethanol $70 \%$ for $30 \mathrm{~min}$ and left in the laboratory for 24 hours. The procedure was repeated five times. After five days the extract was filtered by filter paper. The obtained solution was evaporated to a thick mass on a water path under vacuum and hardened after cooling to give a gummy matter of propolis (Boeru and Derevici, 1978).

\section{Propolis-Water Extracts (PWE):}

Ten grams of cleaned crude propolis was taken and dissolved in $100 \mathrm{ml}$ distilled water. The mixture was gradually heated and allowed to boil for three min. The extract was then cooled in the refrigerator. This was repeated for three times. After three days the extract was filtered by filter paper. The obtained liquid was condensed to thick mass under a water bath and vacuum, which hardened after cooling. From the prepared extract $10 \%$ propolis solution was made in distilled water. 


\section{Antibacterial Effect of the Propolis:}

The agar-well diffusion method (Crespo et al. 1990) was performed to study the in-vitro effects of the two propolis extracts (PEE and PWE) as inhibitors of the growth of three bacterial species $(B$. subtilis, $E$. coli and $K$. pneumoniae). Three concentrations were tested (2, 4 and $8 \mathrm{ppm})$, and 4 replicates for each treatment were used. The inhibition rates of growth were observed and evaluated. The data were statistically analyzed by ANOVA and tabulated.

\section{Results and discussion}

This experiment was performed to evaluate the effect of propolis extracts on the human bacterial growth (Gram-positive and Gram-negative species). The tested bacterial species were Bacillus subtilis, Escherichia coli and Klebsiella pneumoniae. Two propolis extracts were used in this experiment (propolis-ethanol extract and propolis-water extract). The obtained data are explained and discussed as follows:

\section{Effects of propolis ethanol $70 \%$ extract on the bacterial growth:}

Data in table (1) show the in-vitro effect of propolis-ethanol extract $(70 \%)$ with three different concentrations $(2,4$ and $8 \mathrm{ppm})$ on the growth of the three tested bacterial species. Increasing extract concentration resulted in increased zone of growth inhibition of the three tested bacteria species where, at $8 \mathrm{ppm}$ the growth inhibition zones were 14.3, 21.3 and $30.0 \mathrm{~mm}$ for $B$. subtilis, E. coli and $K$. pneumoniae, respectively. On the other hand, the lowest concentrations showed the lowest growth inhibition for all bacterial species $(9.3,15.3$ and 22.6 $\mathrm{mm}$, respectively). The medium concentration (4 ppm) was intermediate (Table 1). The results are matching with what found by Pepeljnjak et al. (1985) who mentioned that the amounts of 3,5,7trihydroxyflavone and of 5,7-dihydroxyflavonone were determined chromatographically in individual propolis samples and affected the growth of $B$. subtilis.

These findings confirm the study of Hellinger (2000) who stated that propolis has antibacterial activity against a range of commonly encountered cocci and Gram-positive rods, including the human tubercle bacillus, but only limited activity against Gram-negative bacilli and possibly attributable to its high flavonoid content. Also the results are close to what was reached by Sforcin, and Bankova (2011).

$K$. pneumoniae was the most affected species by propolis-ethanol $70 \%$ extraction with an average inhibition zone of $25.2 \mathrm{~mm}$ followed by E. coli (18.2 $\mathrm{mm})$ and then B. subtilis $(11.8 \mathrm{~mm})$. The findings are close to what was gained by Gebara et al. (2002) and Ophori and Wemabu (2010).

Table 1. Effect of propolis-ethanol extraction on three bacterial species

\begin{tabular}{lccc}
\hline \multirow{2}{*}{ Concentration } & \multicolumn{3}{c}{ Growth inhibition zone $(\mathrm{mm})$} \\
\cline { 2 - 4 } & B. subtilis & E. coli & K. pneumoniae \\
\hline $2 \mathrm{ppm}$ & 9.3 & 15.3 & 22.6 \\
$4 \mathrm{ppm}$ & 11.7 & 18.0 & 23.0 \\
$8 \mathrm{ppm}$ & 14.3 & 21.3 & 30.0 \\
Total & 35.3 & 54.6 & 75.6 \\
Mean & 11.8 & 18.2 & 25.2 \\
Control & 0.0 & 0.0 & 0.0 \\
\hline F-values: For B. subtilis $=35.176$ & $\mathrm{p}=0.106$. For E. coli=17.694 & $\mathrm{p}=0.149$. For K. pneumoniae $=12.545 \quad \mathrm{p}=$ \\
0.012. & & &
\end{tabular}

\section{Effect of propolis-water extract on the bacterial growth:}

Table (2) represents the inhibition zone caused by propolis-water extract on the three tested bacteria species. No inhibition could be found except for the B. subtilis which was affected by propolis Concentrations 4 and 8 ppm.(growth inhibition zone 4.3 and $8 \mathrm{~mm}$, respectively).

Table 2. Effect of propolis-water extraction on three bacteria species

\begin{tabular}{lccc}
\hline \multirow{2}{*}{ Concentrations } & \multicolumn{3}{c}{ Growth inhibition zone $(\mathrm{mm})$} \\
\cline { 2 - 4 } & B. subtilis & E. coli & K. pneumoniae \\
\hline $2 \mathrm{ppm}$ & 0.0 & 0.0 & 0.0 \\
$4 \mathrm{ppm}$ & 4.3 & 0.0 & 0.0 \\
$8 \mathrm{ppm}$ & 8.0 & 0.0 & 0.0 \\
Total & 12.3 & 0.0 & 0.0 \\
Mean & 4.1 & 0.0 & 0.0 \\
Control & 0.0 & 0.0 & 0.0 \\
\hline
\end{tabular}

F-values: For B. subtilis $=56.333 \mathrm{p}=0.084$. For E. coli=0. For K. pneumoniae $=0$.

More studies are needed and further proof that propolis has countless health benefits. 


\section{References}

1.Boeru, V. and A. Derevici (1978): Some chemical and physical data on Romanian propolis. Apimondia "propolis" Bucharest 18: 1926.

2. Crespo, M.E.; Jimenez, J.; Gomis, E. and C. Nararro (1990): Antimicrobial activity of essential oil of Tymus scrpylloides subspecies gadrensis. Micro. Bios. 6: 181-184.

3. Dandiya, P.C. (1991): Antibacterial, Antifungal, antiamoebic, anti-inflammatory and antipyretic studies on propolis bee product. J. Ethnopharmacol. 35: 77-78.

4. Gebara, E.C.E.; Lima, L.A. and M.P.A. Mayer (2002): Propolis antimicrobial activity against periodontopathic bacteria. Braz. J. Microbiol. 33(4): 1517-1521.

5. Havsteen, B. (1983): Flavonoids: a class of natural products of high pharmacological potency. Biochem. Pharmacol. 32: 1141-1148.

6. Hellinger, W.C. (2000): Confronting the problem of increasing antibiotic resistance. South Med. J. 93(9): 842-848.
7. Ophori, E.A. and E.C. Wemabu (2010): Antimicrobial activity of propolis extract on bacteria isolated from nasopharynx of patients with upper respiratory tract infection admitted to Central Hospital, Benin City, Nigeria. African J. Microbiol. Res. 4(16): 1719-1723.

8. Pepeljnjak, S.; Jalsenjak, I. and D. Maysinger (1985): Flavonoid content in propolis extracts and growth inhibition of Bacillus subtilis. Pharmazie: 40(2): 122-125.

9. Philippe, J.L.; Vitrac, X.; Bernard, L.; Bruyere, F. and A. Scotto (2011): Propolis can potentialise the anti-adhesion activity of proanthocyanidins on uro-pathogenic Escherichia coli in the prevention of recurrent urinary tract infections. BMC Research Notes. 4:500-522.

10.Sforcin, J.M. and V. Bankova (2011): Propolis: is there a potential for the development of new drugs? J. Ethno-pharmacol. 133: 253-260.

11.Zumla, A. and A. Lulat (1989): Honey: a remedy rediscovered. J. R. Soc. Med. 82: 384385 . 


\section{الملخص العربي \\ تأثير صمغ النحل (البرويوليس) على بعض أنواع البكتيريا التي تصيب الإنسان \\ (Bacillus subtilis, Escherichia coli and Klebsiella pneumoniae)}

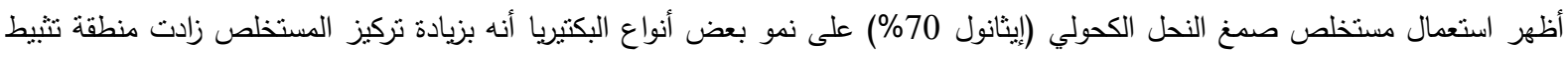

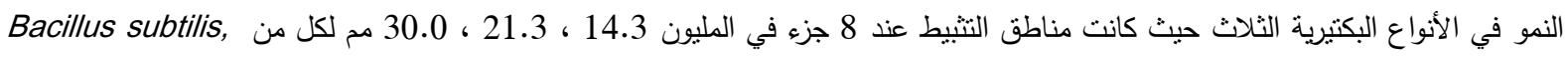
Escherichia coli and Klebsiella pneumoniae

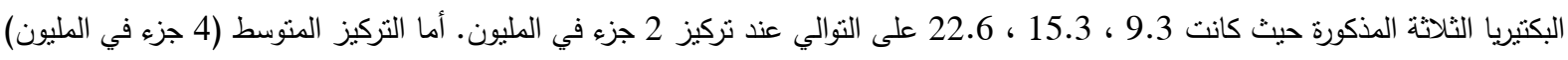

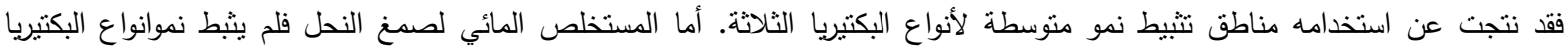

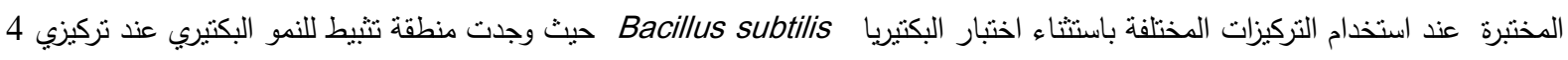
، 8 جزء في المليون ، وبلغت هذه المناطق 4.3 ، 8.0 مم على الترتيب. 